\title{
$\alpha 6 \beta 4$ Integrin and Dystroglycan Cooperate to Stabilize the Myelin Sheath
}

\author{
Alessandro Nodari, ${ }^{1}$ Stefano C. Previtali, ${ }^{2}$ Gabriele Dati, ${ }^{1}$ Simona Occhi, ${ }^{1}$ Felipe A. Court, ${ }^{1}$ Cristina Colombelli, ${ }^{1}$ \\ Desirée Zambroni, ${ }^{1}$ Giorgia Dina, ${ }^{2}$ Ubaldo Del Carro, ${ }^{2}$ Kevin P. Campbell, ${ }^{3}$ Angelo Quattrini, ${ }^{2}$ Lawrence Wrabetz, ${ }^{1}$ and \\ M. Laura Feltri ${ }^{1}$ \\ ${ }^{1}$ Department of Biological and Technological Research and ${ }^{2}$ Institute of Experimental Neurology and Department of Neurology, San Raffaele Scientific \\ Institute, 20132 Milan, Italy, and ${ }^{3}$ Howard Hughes Medical Institute and Departments of Molecular Physiology and Biophysics, Internal Medicine, and \\ Neurology, University of Iowa Carver College of Medicine, Iowa City, Iowa 52242
}

\begin{abstract}
Schwann cells integrate signals deriving from the axon and the basal lamina to myelinate peripheral nerves. Integrin $\alpha 6 \beta 4$ is a laminin receptor synthesized by Schwann cells and displayed apposed to the basal lamina. $\alpha 6 \beta 4$ integrin expression in Schwann cells is induced by axons at the onset of myelination, and rises in adulthood. The $\beta 4$ chain has a uniquely long cytoplasmic domain that interacts with intermediate filaments such as dystonin, important in peripheral myelination. Furthermore, $\alpha 6 \beta 4$ integrin binds peripheral myelin protein 22, whose alteration causes the most common demyelinating hereditary neuropathy. All these data suggest a role for $\alpha 6 \beta 4$ integrin in peripheral nerve myelination. Here we show that ablating $\alpha 6 \beta 4$ integrin specifically in Schwann cells of transgenic mice does not affect peripheral nerve development, myelin formation, maturation, or regeneration. However, consistent with maximal expression in adult nerves, $\alpha 6 \beta 4$ integrin-null myelin is more prone to abnormal folding with aging. When the laminin receptor dystroglycan is also ablated, major folding abnormalities occur, associated with acute demyelination in some peripheral nervous system districts. These data indicate that, similar to its role in skin, $\alpha 6 \beta 4$ integrin confers stability to myelin in peripheral nerves.
\end{abstract}

Key words: $\alpha 6 \beta 4$ integrin; dystroglycan; myelin; Schwann cells; targeted mutagenesis; peripheral nervous system

\section{Introduction}

Schwann cells interact with peripheral axons to form myelinated or nonmyelinated fibers. Spiraling and compaction of the glial membrane in myelin assures fast conduction of nerve impulses and involves a network of signals between axons, extracellular matrix, and Schwann cells (for review, see Feltri and Wrabetz, 2005).

$\alpha 6 \beta 4$ integrin is a laminin receptor expressed by epithelia (Kajiji et al., 1989), endothelia (Kennel et al., 1992; Klein et al., 1993), thymocytes (Wadsworth et al., 1992), Schwann cells (Einheber et al., 1993), and a component of hemidesmosomes (for review, see Quaranta and Jones, 1991). Multiple observations

\footnotetext{
Received Jan. 24, 2008; revised May 23, 2008; accepted May 27, 2008.

This work was supported by the National Institutes of Health (R01-NS045630 to M.L.F., R01-NS055256 to L.W., and Senator Paul D. Wellstone Muscular Dystrophy Cooperative Research Center Grant U54-NS053672 to K.P.C.), Telethon Italia (GGP04019 to M.L.F. and GGP071100 to L.W.), and Istituto Superiore di Sanità e Fondo per gli Investimenti della Ricerca di Base TissueNet (A.Q.). K.P.C. is an investigator of the Howard Hughes Medical Institute. We thank C. Ferri for superb technical assistance; E. Fuchs (Rockefeller University, New York, NY) and J. Dowling (University of Michigan, Ann Arbor, MI) for the $\mathrm{m} \beta 4$ int $\lambda$ C genomic clone; P. Orban (University of Montreal, Montreal, Quebec, Canada) for the pFIrt1 vector; V. Broccoli for TBV ${ }_{2}$ embryonic stem (ES) cells; Telethon Core Facility for Conditional Mutagenesis (San Raffaele Institute, Milan, Italy) for injecting targeted ES cells; and P. Brophy and D. Sherman (University of Edinburgh, Edinburgh, UK), E. Peles (Weizmann Institute, Rehovot, Israel), V. Lee (University of Pennsylvania, Philadelphia, PA), and S. Kennel (Oak Ridge National Laboratory, Oak Ridge, TN) for antibodies.

Correspondence should be addressed to M. Laura Feltri, Department of Biological and Technological Research,

San Raffaele Scientific Institute, Via Olgettina 58, 20132 Milano, Italy. E-mail: feltri.laura@hsr.it.

G. Dati's present address: RBM, Merck Serono Società Affiliata, Turin, Italy.

F. A. Court's present address: Pontificia Universidad Católica de Chile, 114-D Santiago, Chile. DOI:10.1523/JNEUROSCI.0326-08.2008

Copyright $\odot 2008$ Society for Neuroscience $\quad 0270-6474 / 08 / 286714-06 \$ 15.00 / 0$
}

suggest that $\beta 4$ integrin may be important in myelination. First, $\beta 4$ integrin expression in Schwann cells is induced by axons during myelination (Einheber et al., 1993; Feltri et al., 1994). In contrast to $\alpha 6 \beta 1$ integrin expression, which decreases during myelination (Einheber et al., 1993), $\alpha 6 \beta 4$ appears during myelin synthesis, and its expression continues to increase in adulthood (Previtali et al., 2003b; Verheijen et al., 2003). Thus, Schwann cells may switch their laminin-binding integrins from $\alpha 6 \beta 1$ to $\alpha 6 \beta 4$ to promote or maintain myelination (Einheber et al., 1993). Second, $\beta 4$ integrin has a long cytoplasmic domain, not homologous with other $\beta$ integrins, that mediates signals through recruitment of Shc and PI3-kinase, affects MAPK (mitogen-activated protein kinase) and NF- $\kappa \mathrm{B}$ (nuclear factor $\kappa \mathrm{B})$ nuclear translocation (for review, see Giancotti and Tarone, 2003), and interacts with intermediate filaments such as dystonin (Litjens et al., 2003), which has a Schwann cell autonomous role in myelination (Bernier et al., 1998). Third, $\alpha 6 \beta 4$ integrin in epithelia amplifies neuregulin signaling (Guo et al., 2006), which is crucial at multiple stages of Schwann cell development (for review, see Nave and Salzer, 2006). Finally $\alpha 6 \beta 4$ integrin interacts with PMP22, a myelin protein mutated in Charcot-MarieTooth 1A neuropathy (Amici et al., 2006). Against a role for $\alpha 6 \beta 4$ integrin, myelination starts normally in newborn nerves and dorsal root ganglia explants from mice dying at postnatal day 1 (P1) as a result of $\beta 4$ inactivation (Frei et al., 1999). However, $\beta 4$ expression in Schwann cells is just beginning in P1 mice and follows, not precedes, the onset of myelination (Previtali et al., 
$2003 \mathrm{~b})$. Thus, a role for $\beta 4$ in myelin maturation or maintenance could not be addressed from these studies.

Therefore, we generated mice lacking $\beta 4$ integrin in Schwann cells. Surprisingly, we find that absence of $\beta 4$ integrin does not impact development, maturation, or regeneration of myelinated fibers. $\beta 4$ integrin contributes instead to stabilize myelin, because its absence causes an increase of age-related formation of myelin infoldings. Another laminin receptor, dystroglycan, is coexpressed with $\alpha 6 \beta 4$ integrin, and its deletion causes abnormal folding of myelin sheaths (Saito et al., 2003). Deletion of both dystroglycan and $\beta 4$ integrin aggravates the folding phenotype of dystroglycan mutants in ventral roots, causing a dramatic agedependent demyelination. Thus, the two receptors cooperate to stabilize myelin.

\section{Materials and Methods}

For generation of $\beta 4$ integrin "floxed" allele, antibodies used, PCR, and rotarod, see supplemental methods (available at www.jneurosci.org as supplemental material).

Generation of $\beta 4$ integrin conditional null mice. $\mathrm{P}_{0} \mathrm{Cre}\left(\mathrm{mP}_{0}\right.$ TOTACre) and dystroglycan (DG) floxed mice have been described previously (Feltri et al., 1999, 2002; Moore et al., 2002). $\mathrm{P}_{0} \mathrm{Cre}, \beta 4^{\mathrm{F} /+}$, and $\mathrm{DG}^{\mathrm{F} /+}$ lines were maintained by backcrosses with $\mathrm{C} 57 \mathrm{BL} / 6$ mice. $\mathrm{P}_{0}$ Cre mice used in the experiments were congenic in C57BL/6. Progeny used in this study was N3-N7 generations congenic in C57BL/6. In the experiments, littermates or mice deriving from the same parents were compared.

Immunohistochemistry. Immunohistochemistry on frozen nerves was conducted as described previously (Feltri et al., 2002). Immunohistochemistry on teased nerve fibers was conducted as described previously (Occhi et al., 2005), except for $S 100 / \beta 1$ integrin staining, in which acetone was omitted, and fibers were permeabilized in $0.2 \%$ Triton X-100 and stained immediately after dissection.

Western blotting. Western blotting was conducted under reducing conditions as described previously (Previtali et al., 2003b).

Morphology. Morphology on semithin and ultrathin sections of nerves was conducted as described previously (Wrabetz et al., 2000).

Electrophysiological analysis. Electrophysiological analysis was conducted as described previously (Occhi et al., 2005).

Crush injury. Crush injury was conducted as described previously (Quattrini et al., 1996).

Bromodeoxyuridine incorporation and terminal deoxynucleotidyl transferase-mediated biotinylated UTP nick end labeling assays. Bromodeoxyuridine (BrdU) incorporation and terminal deoxynucleotidyl transferase-mediated biotinylated UTP nick end labeling (TUNEL) assays were performed as described previously (Feltri et al., 2002).

Image acquisition. Images were acquired using confocal (PerkinElmer UltraView ERS and Leica TCS-SP5) or fluorescence microscopes (Leica DM 5000 B).

Image analysis was performed using Adobe Photoshop CS.

Statistical analysis. Statistical analysis was performed using Excel (Office X for Mac), StatView (version 5.0 for Mac), and SPSS (version 11 for Mac).

\section{Results}

Generation of a $\beta 4^{\mathrm{F}}$-floxed allele and null mice

$\beta 4$ integrin conditional or constitutive null mice were generated using the Cre/LoxP system. Constitutive null mice reproduced the skin blistering phenotype previously reported (supplemental Fig. 1, available at www.jneurosci.org as supplemental material) (Dowling et al., 1996; van der Neut et al., 1996).

Schwann cell-specific ablation in $\beta 4^{\mathrm{F} / \mathrm{F}} / / \mathrm{P} 0 \mathrm{Cre}$ mice does not impair myelinogenesis

Schwann cell-specific ablation was achieved by mating $\beta 4^{\mathrm{F} / \mathrm{F}}$ mice with mice that express Cre recombinase in Schwann cells (Feltri et al., 1999). In mutant sciatic nerves, $\beta 4$ protein was ab-
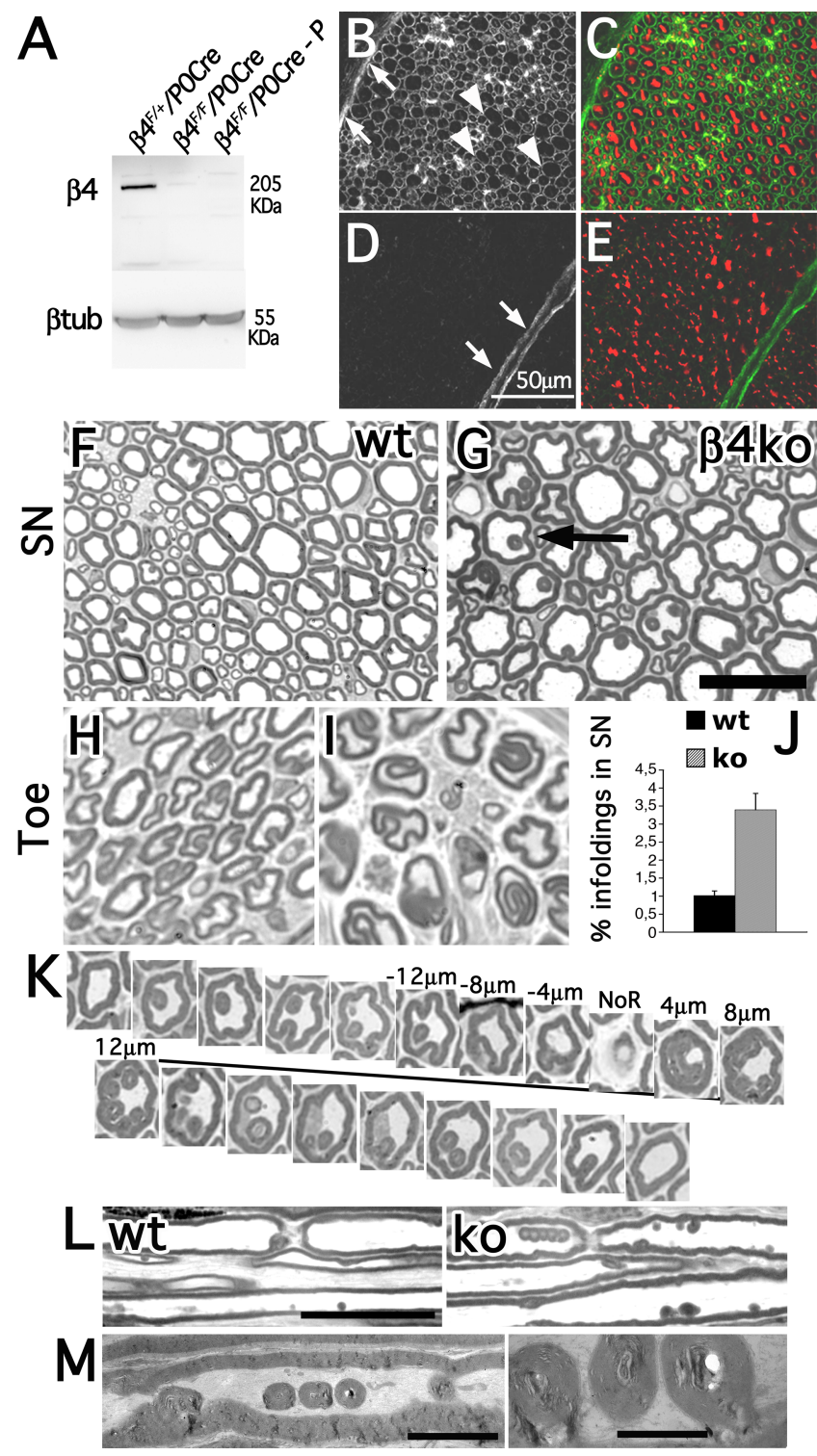

Figure 1. Schwann-cell-specific inactivation of $\beta 4$ integrin causes increased frequency of age-related myelin infoldings. $\boldsymbol{A}$, Western blots from sciatic nerve lysates. $\beta 4^{\mathrm{F} / \mathrm{FPOC}} \mathrm{Cr}-\mathrm{P}$ is a lysate deprived of the perineurium. $\boldsymbol{B}-\boldsymbol{E}$, Transversal sections of sciatic nerves from $\beta 4^{\mathrm{F} /+}$ POCre $(\boldsymbol{B}, \boldsymbol{C})$ and $\beta 4^{\mathrm{F} / \mathrm{F} P O C r e}(\boldsymbol{D}, \boldsymbol{E})$ mice stained with anti- $\beta 4$ integrin $(\boldsymbol{B}, \boldsymbol{D})$ and antineurofilament antibodies (in red; $\boldsymbol{C}, \boldsymbol{E}$ ) show absence of $\beta 4$ integrin protein in $\beta 4^{\mathrm{F} / \mathrm{F}} \mathrm{POCre}$ Schwann cells, but not perineurial cells (arrows). Arrowheads point to $\beta 4$-positive Schwann cells in control nerves. Scale bar, $50 \mu \mathrm{m}$. $\boldsymbol{F}$-I, Transverse sections of 18-month-old sciatic nerves $(\mathrm{SN} ; \boldsymbol{F}, \boldsymbol{G})$ and 12 -month-old digital nerves in the toes $(\boldsymbol{H}, \boldsymbol{I})$ from wild-type (wt; $\boldsymbol{F}, \boldsymbol{H})$ and $\beta 4$ integrin mutant $(\boldsymbol{G}, \boldsymbol{I})$ mice. $J$, Quantification of the number of infoldings (arrow in $\boldsymbol{G}$ ) in 12-month-old sciatic nerves as a percentage of the total number of myelinated fibers [wt, $1.02 \pm 0.128$; knock-out (ko), $3.40 \pm 0.454 ; p<0.01$ by paired $t$ test analysis; total, 5114 fibers for wt and 3445 fibers for mutant; $n=3$ animals per genotype]. $\boldsymbol{K}$, Serial transverse sections of a 12-month-old $\beta 4$ integrin-null sciatic nerve demonstrate that folding originates near the nodes of Ranvier (NoR) and follows the fiber for $36-40 \mu \mathrm{m}$. Occasionally we observed myelin infoldings developing from the internode. $L$, "Chains" of infoldings near the node of Ranvier in mutant nerves seen by longitudinal sections. $M$, Electron microscopic analysis shows that the infoldings do not contain axonal structures, but rather amorphous substance. Scale bars: $\mathbf{G}, 25 \mu \mathrm{m} ; \boldsymbol{L}, 25 \mu \mathrm{m} ; \boldsymbol{M}$ (left), $5 \mu \mathrm{m} ; \boldsymbol{M}$ (right), $1.6 \mu \mathrm{m}$.

sent in Schwann cells, but present in perineurial cells (Fig. 1A-E). Mutant mice did not show tremor, gait abnormalities, or atrophy (data not shown). Rotarod performance and neurophysiology were normal (supplemental Fig. 2, available at www.jneurosci. org as supplemental material), as well as morphology of sciatic 


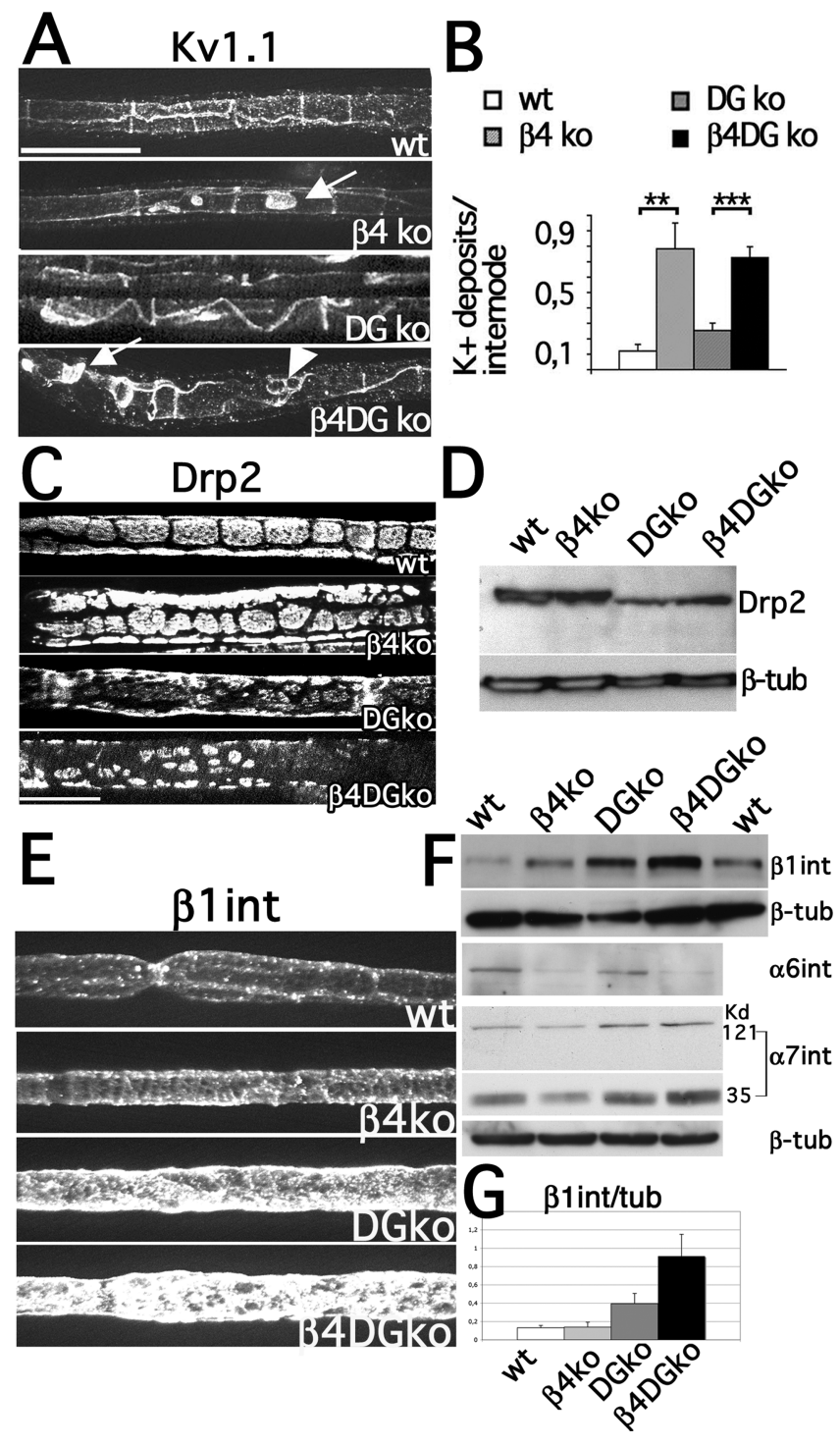

Figure 2. Abnormal $\mathrm{K}^{+}$channel deposits in the internode and upregulation of $\alpha 7 \beta 1$ integrin in mutant mice. $\boldsymbol{A}, \mathrm{K}^{+}$channel staining reveals that the inner and outer mesaxon in $\beta 4$ and $\beta 4 / D G$-null internodes contain abnormal deposits (arrows) and loops (arrowhead). $\boldsymbol{B}$, Quantification of deposits per internode demonstrates that they are specific to the absence of $\beta 4$ integrin [wild type (wt), $0.129 \pm 0.043$; DG-null, $0.240 \pm 0.048$; $\beta 4$ integrin-null, $0.714 \pm$ 0.167 ; and $\beta 4$ integrin/DG-null, $0.719 \pm 0.068 ; \beta 4$ integrin-null vs wt, ${ }^{* *} p<0.05 ; \beta 4$ integrin/DG-null vs DG-null, ${ }^{* * *} p<0.001$ by paired $t$ test]. C, Drp2 staining on teased fibers from the indicated genotypes. $\boldsymbol{D}$, Western blot from sciatic nerve lysates showing Drp2 expression. $\boldsymbol{E}$, Staining with anti- $\beta 1$ integrin antibodies shows that $\beta 1$ integrin is selectively localized in Cajal bands in wt fibers, but not in single- and double-mutant mice. $\boldsymbol{F}, \beta 1$ integrin is upregulated in dystroglycan and double-mutant mice by Western blot analysis, in parallel with the $\alpha 7$ subunit. In reducing condition, the $\alpha 7121$ and $35 \mathrm{kDa}$ proteolytic fragments are detected in nerves (Song et al., 1992). $\alpha 6$ integrin is not upregulated in mutants and almost absent in $\beta 4$ mutants. G, Quantification of $\boldsymbol{F}$. Error bars indicate SEM. Scale bars: $\boldsymbol{A}, 40 \mu \mathrm{m} ; \boldsymbol{C}, 35 \mu \mathrm{m}$.

nerve and spinal roots during development and up to 7 months of age (supplemental Fig. 3, available at www.jneurosci.org as supplemental material).

Mutant Schwann cells display normal proliferation and survival and form normal axonal domains

Although in other systems $\beta 4$ integrin controls cell cycle progression and amplifies neuregulin signaling (Guo et al., 2006), no significant differences between $\beta 4$ integrin-null and control nerves were detected by BrdU incorporation and TUNEL assay (supplemental Fig. 4, available at www.jneurosci.org as supplemental material).

Mutant fibers showed proper localization of Nav (voltagegated sodium) channels, phosphorylated ERM (ezrin-radixinmoesin), Caspr, neurofascin 155/186, and potassium channels (KV1.1) to appropriate nodal-paranodal and juxtaparanodal regions. Finally, the absence of $\beta 4$ integrin did not alter the formation of Schmidt-Lantermann incisures (supplemental Fig. 4, available at www.jneurosci.org as supplemental material).

\section{Absence of $\boldsymbol{\beta} 4$ integrin does not influence nerve regeneration} To test whether $\alpha 6 \beta 4$ integrin is involved in nerve repair after damage (Einheber et al., 1993; Niessen et al., 1994; Quattrini et al., 1996), we studied regeneration after sciatic nerve crush. Axonal regeneration and remyelination were not delayed at 15 or $21 \mathrm{~d}$ (supplemental Fig. 6, available at www.jneurosci.org as supplemental material) and 2 months (data not shown) after crush. Finally, neuromuscular junctions in soleus and sternocleidomastoid muscles of mutant mice at 10 months of age were normal (data not shown).

$\beta 4$ integrin conditional null mice have a late-onset increase in myelin folding

At 12 months of age, mutant sciatic, digital nerves and anterior roots presented a progressive increase in the number of myelin infoldings (Fig. 1). Myelin infoldings may indicate myelin instability, because they occur normally with aging (Knox et al., 1989). Folding usually developed as myelin invaginations $2-4 \mu \mathrm{m}$ away from the node of Ranvier (Fig. $1 K$ ) and appeared as rings of myelin inside the fiber that often formed chains (Fig. $1 \mathrm{~L}$ ). Infoldings appeared to contain extracellular material (Fig. $1 M$ ), suggesting that they are sites of myelin sheath/basal lamina invagination caused by microtrauma. The absence of $\alpha 6 \beta 4$ likely impairs firm attachment of the Schwann cell to the basal lamina, which accelerates the age-related formation of abnormally folded myelin sheaths.

\section{$\beta 4$ integrin and dystroglycan have both redundant and} nonredundant functions

Both $\alpha 6 \beta 4$ integrin and dystroglycan are laminin receptors whose expression is regulated similarly in development (Previtali et al., 2003b). Mice lacking Schwann cell dystroglycan present abnormalities of the nodes of Ranvier and late-onset myelin foldings (Saito et al., 2003; Occhi et al., 2005). To evaluate redundancy between the two receptors, we generated $\beta 4$ integrin/DG double conditional null mice. Rotarod scores of 6- (data not shown) and 12-month-old $\beta 4$ integrin/DG double-null mice (before symptoms develop in single dystroglycan mice) were normal (supplemental Fig. 5, available at www.jneurosci.org as supplemental material). Dystroglycan mice have a neuropathy with reduced nerve conduction velocity, increased $\mathrm{F}$-wave latency, and reduced motor action potential amplitude (Saito et al., 2003). Even if differences were not statistically significant, double-mutant mice showed a further reduction of nerve conduction velocity and of the amplitude of the motor action potential, and an increase in F-wave latency (see Fig. 3).

Dystroglycan mutants showed defective clusterization of sodium channels at nodes of Ranvier (Saito et al., 2003; Occhi et al., 2005), which was not aggravated by the lack of $\beta 4$ integrin (supplemental Fig. 5, available at www.jneurosci.org as supplemental material). The distribution of Schmidt-Lantermann incisures, Caspr at paranodes, and $\mathrm{K}^{+}$channels at juxtaparanodes was normal in double-null mice (supplemental Fig. 5, available at www. jneurosci.org as supplemental material). 


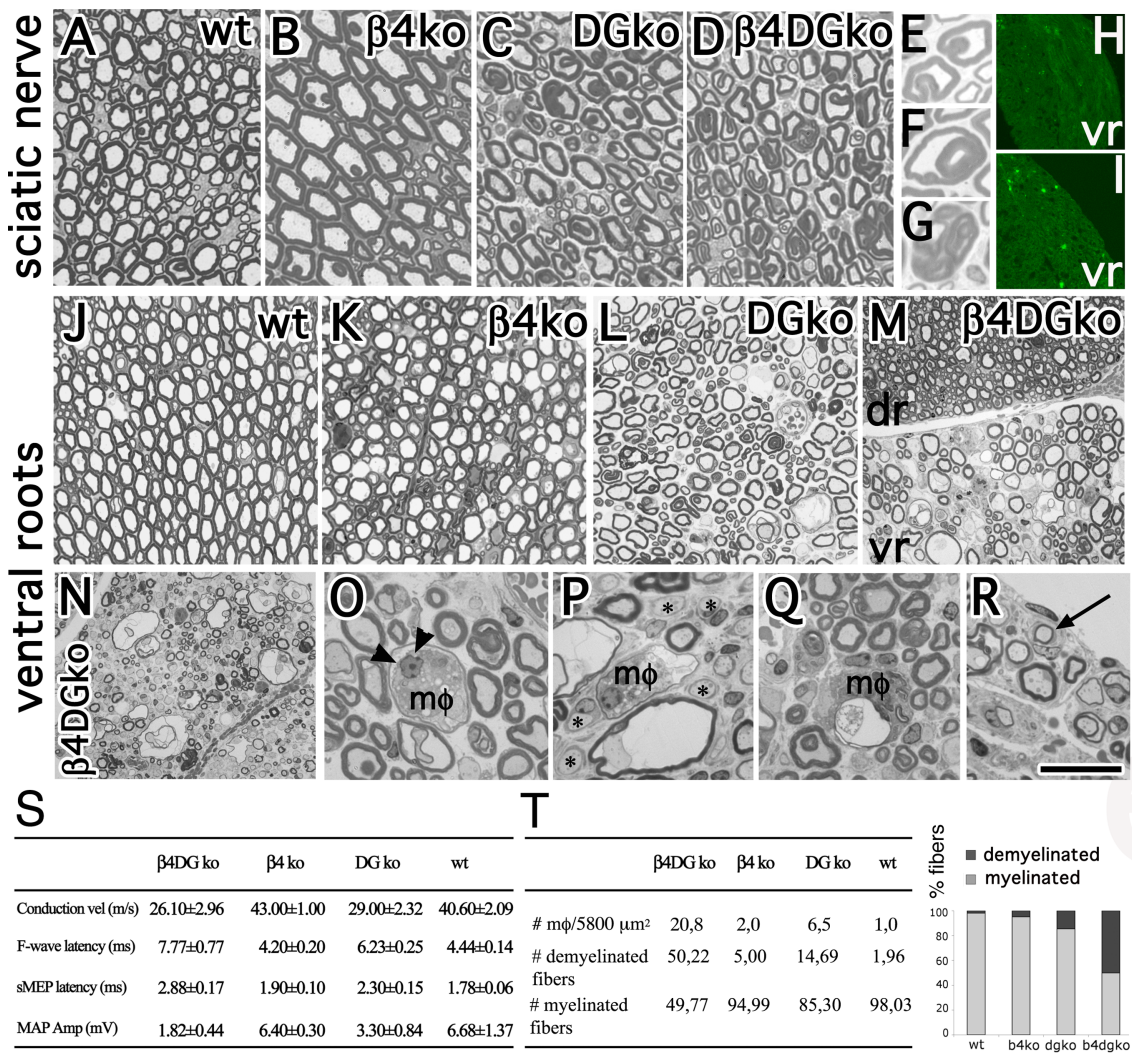

Figure 3. Excessive myelin folding in sciatic nerves, with myelin breakdown and degeneration in roots of double-mutant mice. $\boldsymbol{A}-\boldsymbol{M}$, Transversal semithin sections from 12-month-old sciatic nerves and ventral roots. $A-G$, Both DG-null and doublemutant nerves contain abnormal loops (e.g., in $\boldsymbol{E}$ ), infoldings (e.g., in $\boldsymbol{F}$ ), and outfoldings (e.g., in $\boldsymbol{G}$ ). $J-M$, Ventral roots lacking dystroglycan $(L)$ show hypomyelination. $M-T$, Hypomyelination in double-mutant mice is severe in ventral $[M(\mathrm{vr}), \boldsymbol{N}]$, but not dorsal (dr) roots, with signs of acute demyelination including macrophages $(\mathrm{m} \phi)$ engulfing degenerated axons $(\boldsymbol{O}$, arrowheads) and myelin breakdown products $(\mathbf{O}, \boldsymbol{P}, \mathbf{Q}, \mathrm{m} \boldsymbol{\phi})$, thin myelin sheaths $(\boldsymbol{P})$, and demyelinated axons $(\boldsymbol{P}$, asterisks). $\boldsymbol{R}$, Signs of remyelination (onion bulbs, arrow) are present. $\boldsymbol{H}, \boldsymbol{I}$, Staining with anti-CD11b/CD18 (Mac-1) antibodies reveals the presence of macrophages infiltrating double-mutant $(\boldsymbol{I})$ but rarely wild-type $(\mathrm{wt} ; \boldsymbol{H})$ roots. $\boldsymbol{I}$, The number of demyelinated axons was significantly higher in double- than dystroglycan single-mutant mice ( $p<0.001$ by Student's $t$ test; $n=4$ DG-null and 6 double-null mice). Macrophage infiltration was higher in double mutants than in DG-null mice ( $p<0.001$ by Student's test; $n=6$ DG-null mice, 6 double-mutant mice). S, Neurophysiology in 12-month-old $\beta 4$ integrin/DG-null mice and controls confirms that DG-null mice have a neuropathy with reduced nerve conduction velocity (vel) and increased latencies of motorevoked potential (SMEP) and of F-wave. These parameters worsen in double-mutant mice, although the differences do not reach statistical significance. The reduction in motor action potential (MAP) amplitude (Amp) became statistically different in double mutants compared with wt mice ( $p=0.044$ by paired $t$ test; $n=6$ double-null, $2 \beta 4$ integrin-null, 4 DG-null, 5 wt) Values and SEMs are indicated for each genotype. Scale bar: (in $\boldsymbol{R}) \boldsymbol{A}-\boldsymbol{D}, 30 \mu \mathrm{m} ; \boldsymbol{E}-\mathbf{G}, 11.5 \mu \mathrm{m} ; \boldsymbol{J}-\boldsymbol{M}, 50 \mu \mathrm{m} ; \boldsymbol{N}-\boldsymbol{R}, 25 \mu \mathrm{m}$.
Absence of $\boldsymbol{\beta} 4$ integrin causes dislocation of potassium channels in the internode

Single and double $\beta 4$ integrin/DG-null myelinated internodes contained "deposits" of $\mathrm{K}^{+}$channels, apparently associated with the inner mesaxon (Fig. $2 A$ ). In $\beta 4$ integrin/DG-null myelinated fibers, the inner mesaxon itself, as evidenced by $\mathrm{K}^{+}$channel staining, seemed disorganized (Fig. $2 A$ ). This abnormality was specific to the absence of $\beta 4$ integrin, because it was not present in nerves lacking only dystroglycan.

\section{Drp2 clusters can form in the absence of both $\beta 4$ integrin and dystroglycan}

Drp2, a member of the dystrophin-glycoprotein complex, interacts with periaxin in Schwann cells and localizes in clusters along the myelin fiber (Sherman et al., 2001). In the absence of L-periaxin, Drp2 clusters are absent, whereas in dystroglycan-null nerves, Drp2 expression is reduced, but clusters can form and L-periaxin is normally expressed (Saito et al., 2003; Court et al., 2004). To test whether $\alpha 6 \beta 4$ integrin contributes to Drp2 localization, we stained teased fibers from mutant mice. In $\beta 4$ mutants, Drp2 was normally localized in the expected clustered manner. In nerves lacking dystroglycan, or both dystroglycan and $\alpha 6 \beta 4$ integrin, Drp 2 clusters were similarly small and disorganized (Fig. 2C). By Western blot analysis, the expression of Drp2 was reduced to similar extent in dystroglycan- and double-null mice (Fig. 2D). L-Periaxin expression was unchanged in all the mutants (data not shown). Thus, absence of $\beta 4$ integrin does not impair the formation of Drp2 clusters, even in the absence of dystroglycan.

\section{Expression of $\alpha 7 \beta 1$ integrin in mutant mice}

$\alpha 6 \beta 1$ and $\alpha 7 \beta 1$ integrins are other laminin receptors expressed by Schwann cells (Previtali et al., 2003a,b). $\beta 1$ integrin protein was upregulated by Western blot in sciatic nerves of mutants, especially double $\beta 4$ / dystroglycan-null (Fig. $2 F$ ). $\alpha 7$ integrin was upregulated when dystroglycan was absent, whereas $\alpha 6$ integrin was not regulated in any mutant (Fig. 2F). Instead, $\alpha 6$ integrin was almost absent from $\beta 4$ mutant nerves, suggesting that normally the $\alpha 6$ subunit pairs with $\beta 4$ and not $\beta 1$ in adult nerves. In addition, the localization of $\beta 1$ integrin, normally restricted to Cajal bands found around DRP2 clusters, was diffuse in the outer Schwann cell surface in all mutants, becoming distributed in a manner now similar to $\beta 4$ and dystroglycan (Fig. $2 E$ ) (F. A. Court and M. L. Feltri, unpublished results). Thus, $\alpha 7 \beta 1$ integrins can potentially compensate for the absence of $\alpha 6 \beta 4$ integrin and dystroglycan.

\section{Severe folding abnormalities and demyelination in ventral roots from 及4/DG double-null mice}

Morphologically, sciatic nerves from double $\beta 4$ integrin/dystroglycan mutants presented abnormally folded myelin, with abnormal loops (Fig. 3E), infolding (Fig. 3F), and outfolding (Fig. 3G) similar to those seen in single dystroglycan mice, which increased in number with age (data not shown).

Dorsal roots were not distinguishable between dystroglycan and double conditional null mice (data not shown). Ventral roots from dystroglycan-null mice presented hypomyelination, not previously reported (Fig. $3 L$ ). This hypomyelination was more severe and widespread in double mutants (Fig. $3 M$, vr), potentially explaining the increased F-wave latency. Hypomyelination became evident with age, and at 12 months included signs of acute demyelination, with myelin degeneration, macrophage infiltration (Fig. $3 N-R$ ), and remyelination (Fig. $3 R$, onion bulbs). Macrophages were significantly more numerous in double than in dystroglycan single mutant (Fig. $3 I, T)(p<0.001)$. Electron microscopy showed activated "foamy" macrophages containing myelin or axon debris inside myelin sheaths and surrounding axons (Fig. $4 B-E$ ), as well as hypomyelination and uncompaction of myelin lamellae (Fig. $4 H-K$ ). Macrophages often appeared in association with loose and redundant basal lamina (Fig. 
$4 I$ ), or were stripping the basal lamina away from myelinated fibers (Fig. $4 F, G$ ). Longitudinal sections indicated that macrophages entered at paranodes (Fig. $4 M, N)$. These data suggest that lack of $\alpha 6 \beta 4$ integrin and dystroglycan causes abnormal myelin folding that, coupled with poor attachment to the basal lamina, eventually triggers acute demyelination in roots. Thus dystroglycan and $\beta 4$ integrin cooperate to maintain myelin integrity.

\section{Discussion}

A role for $\beta 4$ integrin in myelination, maintenance, or regeneration has long been suggested. To conclusively address the role of $\alpha 6 \beta 4$ integrin in myelin, we ablated it from Schwann cells of transgenic mice, alone or in combination with dystroglycan, another laminin receptor expressed by myelinating Schwann cells. We show that $\alpha 6 \beta 4$ integrin has a surprisingly minor role in nerve development, function, or regeneration. However, we provide evidence that $\alpha 6 \beta 4$ integrin and dystroglycan together are required to maintain the integrity of myelin sheaths.

\section{Absence of $\alpha 6 \beta 4$ integrin in Schwann cells does not affect Schwann cell functions, but accelerates the folding of myelin sheaths seen in normal nerves with age After extensive analysis, the only differ- ence detected in $\beta 4$ integrin mutant nerves was a slight increase in the frequency of myelin infoldings, normally observed in myelinated fibers with age. These folds are scattered along the internode and concen- trated in small chains at the paranodal- juxtaparanodal regions, and appear as regions where the myelin folds inward, possibly because of mechanical stress. The material contained inside the infoldings appears of extracellular matrix origin. Although the phenotype is less dramatic, this is compara- ble with the structural role of attachment to the basal lamina that a6 $\beta 4$ integrin performs in keratinocytes (Dowling et al., 1996; van der Neut et al., 1996).}

\section{及4 integrin cooperates with dystroglycan to maintain stability of the myelin sheath}

$\alpha 6 \beta 4$ integrin and dystroglycan are both expressed at the onset of myelination and link the cytoskeleton to laminins in the basal lamina. Dystroglycan-null nerves present a late-onset instability of the myelin sheath with formation of myelin infoldings/outfoldings resulting in motor impairment in older animals (Saito et al., 2003; Occhi et al., 2005). This neuropathy was more pronounced in the absence of both $\beta 4$ integrin and dystroglycan, particularly in ventral roots of 12-month-old mice, where extensive myelin folding, hypomyelination, and frequent signs of acute demyelination were observed. It is possible that in the absence of both receptors, myelin instability reaches a threshold that precip- itates myelin destruction, causing an inflammatory response and recruitment of inflammatory cells. Possibly, loose attachment to the basal lamina resulting from the lack of the two receptors also favors the entrance of macrophages, which were frequently observed associated with loose basal lamina, entering at paranodes and residing inside myelin sheaths.

及4 integrin interacts with Pmp22, but mutant mice have different severity of phenotypes

$\beta 4$ integrin has recently been shown to form a complex with Pmp22 (Amici et al., 2006). Heterozygous loss-of-function mutations in PMP22 in mice and men cause a mild tomacular neuropathy, evident only after compression [hereditary neuropathy with liability to pressure palsy (HNPP)]. Heterozygous null mice for Pmp22 resemble HNPP pathology (Adlkofer et al., 1995), whereas homozygous null mice have a severe dysmyelinating and demyelinating neuropathy with both hypomyelination and tomacula (Adlkofer et al., 1995; Amici et al., 2006). In these mice, an impaired organization of the basal lamina and a drastic reduction in the levels of $\beta 4$ integrin was reported, suggesting a role for Pmp22 in stabilizing laminin-integrin interactions (Amici et al., 
2006). A hypothesis arising from this observation is that lamininintegrin interactions at the basal lamina contribute to the stability of the myelin sheath. Even if $\beta 4$ integrin mutant mice have a well organized and adherent basal lamina, and a milder phenotype than mice lacking one or two copies of Pmp22, our report supports this view, and reinforces the idea that by maintaining adhesion to the basal lamina, $\beta 4$ integrin indirectly maintains the integrity of the myelin sheath.

\section{References}

Adlkofer K, Martini R, Aguzzi A, Zielasek J, Toyka KV, Suter U (1995) Hypermyelination and demyelinating peripheral neuropathy in Pmp22deficient mice. Nat Genet 11:274-280.

Amici SA, Dunn Jr WA, Murphy AJ, Adams NC, Gale NW, Valenzuela DM, Yancopoulos GD, Notterpek L (2006) Peripheral myelin protein 22 is in complex with $\alpha 6 \beta 4$ integrin, and its absence alters the Schwann cell basal lamina. J Neurosci 26:1179-1189.

Bernier G, De Repentigny Y, Mathieu M, David S, Kothary R (1998) Dystonin is an essential component of the Schwann cell cytoskeleton at the time of myelination. Development 125:2135-2148.

Court FA, Sherman DL, Pratt T, Garry EM, Ribchester RR, Cottrell DF, Fleetwood-Walker SM, Brophy PJ (2004) Restricted growth of Schwann cells lacking Cajal bands slows conduction in myelinated nerves. Nature 431:191-195.

Dowling J, Yu QC, Fuchs E (1996) Beta4 integrin is required for hemidesmosome formation, cell adhesion and cell survival. J Cell Biol 134:559-572.

Einheber S, Milner TA, Giancotti F, Salzer JL (1993) Axonal regulation of Schwann cell integrin expression suggests a role for alpha 6 beta 4 in myelination. J Cell Biol 123:1223-1236.

Feltri ML, Wrabetz L (2005) Laminins and their receptors in Schwann cells and hereditary neuropathies. J Peripher Nerv Syst 10:128-143.

Feltri ML, Scherer SS, Nemni R, Kamholz J, Vogelbacker H, Scott MO, Canal N, Quaranta V, Wrabetz L (1994) Beta 4 integrin expression in myelinating Schwann cells is polarized, developmentally regulated and axonally dependent. Development 120:1287-1301.

Feltri ML, D’Antonio M, Previtali S, Fasolini M, Messing A, Wrabetz L (1999) P0-Cre transgenic mice for inactivation of adhesion molecules in Schwann cells. Ann NY Acad Sci 883:116-123.

Feltri ML, Graus Porta D, Previtali SC, Nodari A, Migliavacca B, Cassetti A, Littlewood-Evans A, Reichardt LF, Messing A, Quattrini A, Mueller U, Wrabetz L (2002) Conditional disruption of beta 1 integrin in Schwann cells impedes interactions with axons. J Cell Biol 156:199-209.

Frei R, Dowling J, Carenini S, Fuchs E, Martini R (1999) Myelin formation by Schwann cells in the absence of beta4 integrin. Glia 27:269-274.

Giancotti FG, Tarone G (2003) Positional control of cell fate through joint integrin/receptor protein kinase signaling. Annu Rev Cell Dev Biol 19:173-206.

Guo W, Pylayeva Y, Pepe A, Yoshioka T, Muller WJ, Inghirami G, Giancotti FG (2006) Beta 4 integrin amplifies ErbB2 signaling to promote mammary tumorigenesis. Cell 126:489-502.

Kajiji S, Tamura RN, Quaranta V (1989) A novel integrin (alpha E beta 4) from human epithelial cells suggests a fourth family of integrin adhesion receptors. EMBO J 8:673-680.

Kennel SJ, Godfrey V, Ch'ang LY, Lankford TK, Foote LJ, Makkinje A (1992) The beta 4 subunit of the integrin family is displayed on a restricted subset of endothelium in mice. J Cell Sci 101:145-150.

Klein S, Giancotti FG, Presta M, Albelda SM, Buck CA, Rifkin DB (1993)
Basic fibroblast growth factor modulates integrin expression in microvascular endothelial cells. Mol Biol Cell 4:973-982.

Knox CA, Kokmen E, Dyck PJ (1989) Morphometric alteration of rat myelinated fibers with aging. J Neuropathol Exp Neurol 48:119-139.

Litjens SH, Koster J, Kuikman I, van Wilpe S, de Pereda JM, Sonnenberg A (2003) Specificity of binding of the plectin actin-binding domain to beta4 integrin. Mol Biol Cell 14:4039-4050.

Moore SA, Saito F, Chen J, Michele DE, Henry MD, Messing A, Cohn RD, Ross-Barta SE, Westra S, Williamson RA, Hoshi T, Campbell KP (2002) Deletion of brain dystroglycan recapitulates aspects of congenital muscular dystrophy. Nature 418:422-425.

Nave KA, Salzer JL (2006) Axonal regulation of myelination by neuregulin 1. Curr Opin Neurobiol 16:492-500.

Niessen CM, Cremona O, Daams H, Ferraresi S, Sonnenberg A, Marchisio PC (1994) Expression of the integrin alpha 6 beta 4 in peripheral nerves: localization in Schwann and perineural cells and different variants of the beta 4 subunit. J Cell Sci 107:543-552.

Occhi S, Zambroni D, Del Carro U, Amadio S, Sirkowski EE, Scherer SS, Campbell KP, Moore SA, Chen ZL, Strickland S, Di Muzio A, Uncini A, Wrabetz L, Feltri ML (2005) Both laminin and Schwann cell dystroglycan are necessary for proper clustering of sodium channels at nodes of Ranvier. J Neurosci 25:9418-9427.

Previtali SC, Dina G, Nodari A, Fasolini M, Wrabetz L, Mayer U, Feltri ML, Quattrini A (2003a) Schwann cells synthesize alpha7betal integrin which is dispensable for peripheral nerve development and myelination. Mol Cell Neurosci 23:210-218.

Previtali SC, Nodari A, Taveggia C, Pardini C, Dina G, Villa A, Wrabetz L, Quattrini A, Feltri ML (2003b) Expression of laminin receptors in Schwann cell differentiation: evidence for distinct roles. J Neurosci 23:5520-5530.

Quaranta V, Jones JC (1991) The internal affairs of an integrin. Trends Cell Biol 1:2-4.

Quattrini A, Previtali S, Feltri ML, Canal N, Nemni R, Wrabetz L (1996) Beta 4 integrin and other Schwann cell markers in axonal neuropathy. Glia 17:294-306.

Saito F, Moore SA, Barresi R, Henry MD, Messing A, Ross-Barta SE, Cohn RD, Williamson RA, Sluka KA, Sherman DL, Brophy PJ, Schmelzer JD, Low PA, Wrabetz L, Feltri ML, Campbell KP (2003) Unique role of dystroglycan in peripheral nerve myelination, nodal structure, and sodium channel stabilization. Neuron 38:747-758.

Sherman DL, Fabrizi C, Gillespie CS, Brophy PJ (2001) Specific disruption of a Schwann cell dystrophin-related protein complex in a demyelinating neuropathy. Neuron 30:677-687.

Song WK, Wang W, Foster RF, Bielser DA, Kaufman SJ (1992) H36-alpha 7 is a novel integrin alpha chain that is developmentally regulated during skeletal myogenesis. J Cell Biol 117:643-657.

van der Neut R, Krimpenfort P, Calafat J, Niessen CM, Sonnenberg A (1996) Epithelial detachment due to absence of hemidesmosomes in integrin beta 4 null mice. Nat Genet 13:366-369.

Verheijen MH, Chrast R, Burrola P, Lemke G (2003) Local regulation of fat metabolism in peripheral nerves. Genes Dev 17:2450-2464.

Wadsworth S, Halvorson MJ, Coligan JE (1992) Developmentally regulated expression of the beta 4 integrin on immature mouse thymocytes. J Immunol 149:421-428.

Wrabetz L, Feltri ML, Quattrini A, Imperiale D, Previtali S, D’Antonio M, Martini R, Yin X, Trapp BD, Zhou L, Chiu SY, Messing A (2000) P(0) glycoprotein overexpression causes congenital hypomyelination of peripheral nerves. J Cell Biol 148:1021-1034. 